\title{
The Small Details in the Archives and the Meaning of a Non-existent Photography from the Home of a Stationer in Helsingborg
}

\author{
By \\ Karin Gustavsson
}

\begin{abstract}
This article describes and problematizes the skills that are used when researching analogue archives. The article deals with the process that operates when a researcher finds small details in archival records that makes it possible to generate a story. Whether it is skill or luck that enables one to find the phenomena that create meaning is also discussed. The empirical example is fetched from the "Swedish Town project" that was initiated with the aim to write a new kind of urban history in the 1940s by Swedish art historian Gregor Paulsson. The researcher Börje Hanssen conducted field work in the city of Helsingborg in southern Sweden during the summers in 1942, 1943 and 1944. The "Swedish Town"-project explored urban history through both traditional sources such as archives, but also by interviews with contemporary town inhabitants and photographs. In the article we meet both Hanssen and some of his interviewees, and his working methods, his texts and some photographs are being analyzed. Börje Hanssen later became an influential ethnologist and in this article we encounter him in the beginning of his career. In order to examine the role played by one small detail in a large amount of material, and how such a detail can influence the researcher's interpretations, Roland Barthes concepts of punctum and studium are used in the article, in order to create meaning out of small, everyday and often seemingly insignificant phenomena. Punctum and studium are fruitful analytical tools, not only in analyzing photographs, which was Barthes original use of the concept but also in other contexts, in this case archival records. The article thus discusses when a detail becomes the punctum that changes the researcher's mindset and enables new knowledge to be produced.
\end{abstract}

Keywords: Field work, Knowledge production, Archives, Photography, Punctum and Studium, Urban history.

Gustavsson, Karin: "The Small Details in the Archives and the Meaning of a Non-existent Photography from the Home of a Stationer in Helsingborg", Culture Unbound, Volume 12, issue 1, 2020: 173-195. Published by Linköping University Electronic Press: http://www.cultureunbound.ep.liu.se 


\section{Introduction}

In July 1944 the Malmqvist family, who lived in Helsingborg, a town located on the coast of southern Sweden, received a visit from a young man who asked them questions about their life at home and at work, their leisure interests and activities, their eating habits, and much more. He made thorough notes, drew sketches of the furniture arrangements in the various rooms, and also took a couple of photographs. The family consisted of a husband and wife in their mid-30s and two school-age boys. The reason for the man's visit to the home in the district of Tågaborg north of the city centre was that, a day earlier, he had entered the stationery store on one of the main streets in the centre of town where the husband and wife both worked. There, he had introduced himself as Börje Hanssen, a student from Stockholm University who, at the time, was involved in a large project entitled Svensk miljö ("Swedish environment"), a study of the changes that had occurred in Swedish homes and towns during the last 100 years. The project was supervised by Professor Gregor Paulsson (1889-1977) from the Department of Art History at Uppsala University. Hanssen was part of a group of researchers that conducted field studies in a number of Swedish towns and urban areas for several years during the 1940s. Their work was intended to result in a commemorative book that was to be finished and released in time for the celebration of the 100-year anniversary of the association Svensk Form, then known as Svenska Slöjdföreningen (The Swedish Society of Crafts and Design) in the autumn of 1945 (Dahlgren 2016: 78).

Traces of Hanssen's visit to the Malmqvist family can now be found in archival records. The aim of this article is to describe and problematize the skills that are used when researching analogue archives. One of the ethnological competences is to create meaning and relationships based on small, everyday and often seemingly insignificant phenomena (see, for example, Löfgren 1997: 96, 110 and Svensson 2012: 16f). In this article, I will describe the process when I look for the details in archived material that make it possible to generate a story, and I will discuss whether it is skill or luck that enables me to find the phenomena that create meaning. I will focus on photographs taken on two different occasions during Hanssen's work: on the one hand the photos he took in the home of the Malmqvist family, and on the other hand a photo that is part of a suite of pictures of Helsingborg's populated environments, but which seems to lack any connection to the other photographs in that series.

Paulsson's intention to produce a commemorative book had to be reconsidered due to many delays and changed circumstances during the years of fieldwork. A written work was instead finally published under the title Svensk stad ("Swedish town"), released in three volumes between 1950 and 1953. Svensk stad has later been regarded as a classical study of urbanisation and industrialisation in Sweden. 
Börje Hanssen (1917-1979) conducted fieldwork in several of the towns on which that publication was based; he came to influence the project greatly and he was also responsible for a large part of the texts that appear in those books. $\mathrm{He}$ eventually became one of Sweden's most influential ethnologists and also enjoyed an international career (Stoklund 1980). A large part of the results of the work that Hanssen performed, such as the Malmqvists' descriptions of what it was like to run a business on Kullagatan in Helsingborg at that time and the family's depictions of everyday life at home, were not included in the published volumes. However, the material that Hanssen (among others) collected on such occasions, as described above-interviews, sketches and photographs-is now stored in the archives of the Nordic Museum in Stockholm.

Before we return to the Malmqvist family, Börje Hanssen and Helsingborg in 1944, and before I address the archived material that I have examined, I will first describe my theoretical starting points and provide some general reflections on ethnology and archives. I will then provide a description of the empirical material on which this article is based and make a short overview of the context in which the fieldworks described in the text were conducted, before moving on to join Börje Hanssen during his visit to the Malmqvist family's home and stationery store. The reader of this article will thus meet both the field-working Börje Hanssen, the practical circumstances surrounding his work in the 1940s, and the researcher of the 2010s trying to follow the tracks of Hanssen through the archived material he created. I will conclude the article with a discussion on the categorisation of material and the importance of the small details when examining a comprehensive amount of archived material.

\section{Theoretical Starting Points}

Ethnologists often create their own material, and they work almost exclusively with qualitative studies (Löfgren 1996: 79f). Being faced with a large amount of already collected material can feel somewhat daunting, and it may also seem of little interest to examine something that other researchers have collected. At the same time, an existing collection of material provides good research opportunities whereby new knowledge can be produced and methodological aspects can be examined and further developed (c.f. Gustavsson 2017). For example, the empirical content of lists of questions and interviews can provide sources of relevant information in connection with new studies involving new issues. Furthermore, the research-related situation that existed at the time the material was collected can be examined and problematized, and contributions can thus be made to studies into conditions and contexts for the production of knowledge. The material I have worked with, including interviews with the Malmqvist family 
and observations from their home, is extremely large. So, what is it that captures my attention, and why? Which details become the bearers of meaning?

In order to examine the role played by one small detail in a large amount of material, and how such a detail can influence the researcher's interpretations, the concepts of punctum and studium can be used. The French linguist and semiotician Roland Barthes has described the element in a photographic image that captures an observer's attention by using the concept of punctum. Studium is everything in the image which, to use Barthes' words, is "perceive[d] quite familiarly" to the observer based on their existing knowledge (Barthes 1981: 25). Studium denotes the expected; not that which surprises the observer, but rather that which confirms what he or she already knows. Punctum, on the other hand, describes that which is temporary and stands out; that which captures the observer's attention (Barthes 1981: 26). Barthes uses the expression "structural rules" when he examines photographs taken in one and the same context by a specific photographer, and he puts into words that which characterises the photographer's imagery. When examining photographs, Barthes sees recurring contradictions in the subject matter depicted in the pictures; elements in the images that are in contrast to each other and create a sort of dualism (Barthes 1981: 23). However, the structure and the rules are extremely subjective; it is Barthes himself, as the observer, who creates them and turns them into tools when he proceeds with his analysis, to which the concepts of studium and punctum are central.

Barthes' concepts have been used to analyse phenomena other than just photographic images. The ethnologist Lotten Gustafsson Reinius examined a museum collection at the Museum of Ethnography in Stockholm with the help of punctum and studium as analytical concepts, and the archaeologist Nanouschka Myrberg used the concepts to interpret archaeological coin findings (Gustafsson Reinius 2009, Myrberg 2012). For Myrberg, this entailed a way of more closely addressing the issue of when and why change has occurred in people's behaviour in the past (Myrberg 2012: 76f). Gustafsson Reinius developed Barthes' concepts by talking about material punctum, whereby tactile and material properties of museum pieces formed part of her understanding of the collection as a phenomenon, and something that could contribute to a clarification of the potential for the production of knowledge that exists in a museum collection (Gustafsson Reinius 2009: 80f).

In this article, the intention is to test these concepts on archived material, with the aim of discovering how a single small detail can become a bearer of meaning and thus contribute to the creation of logic and new knowledge. Even though a photographic image is in one respect unchanging-the subject matter depicted in the image remains the same through the years-its meaning changes depending 
on the identity of the observer. In the same way, a text document can also be said to be unchanging, yet it offers opportunities for the discovery of new meaning through new interpretations. The observer's prior knowledge, expectations and values govern what can be seen in an image, or what he or she is able to read from a written text (Myrberg 2012: 76). A demarcated archive collection, such as Börje Hanssen's personal archive, which is stored at the Nordic Museum, can be said to be unchanging in the same way as an individual photograph. The specific collection remains intact once it has been placed under the care of the archive institution, even though other collections subsequently arrive and add to the institution's collective material. Just like with a single photograph or a single text document, it is constantly possible to reinterpret such a demarcated collection. Its meaning shifts depending on the identity of the observer or the user, and it could be a single small detail that governs the observer's interpretation. Something that represents a meaningful detail for one person, in other words something that contributes to the creation of meaning and context for that person, could be completely overlooked by another person whose work is based on other starting points.

Naturally, the number of objects, and thus the amount of possible interpretations, is much greater in an archive collection than in relation to a single object. Gustafsson Reinius writes about how she experienced "an overwhelming multitude of miscellaneous things" when she entered a museum storeroom and saw the large collections of objects (Gustafsson Reinius 2009: 76). The same feeling can be experienced in relation to the study of archived material. There are many similarities between a collection of documents at an archive institution and a collection of objects at a museum-in both cases, the material is curated with the aim of preserving it for the future, and both categories of material represent people and events from the past and can form a starting point for research in a number of different disciplines. And yet, there are striking differences. The museum collection is the result of a selection process by a professional or group of professionals with the authority and power to decide what should be included in the collective memory that is represented by a collection of objects. Archive collections have often originated outside the influence and reach of the archivist's profession, and they may have been created in a long series of varying contexts. The material that forms the starting point for this article was primarily created as documentation for analyses that were to be presented as text, the production of which was to be closely connected to the actual collection of the material. The ambition of Börje Hanssen and the other members of Gregor Paulsson's work group was not to create a collection of research material that could be used by others in the future, which is precisely one of the intentions of the professionals who create, manage and expand museum collections. 
By studying what a collection consists of and how it is organised, it is possible to draw conclusions about the preferences and ideals of the person(s) who once created the collection (Gustafsson Reinius 2009: 87). The collection itself carries a story about the norms and ideals of those who created it, as well as the practical reality in which they worked. Archives entail possibilities to see the collectors behind the collections, and to bring together and analyse fragments of people from the past to create cohesive descriptions as part of the production of knowledge. It is this aspect that will reunite us with the Malmqvist family and Börje Hanssen a little later in this article.

\section{The Ethnology in the Archives}

Archived material can be compared to parts of a kaleidoscope. The documents that are stored in it can be put together to form an endless array of descriptions and stories. A large number of interesting fragments that are found in different parts of the archives can be put together to form a variety of entities. But while the images created by a kaleidoscope are entirely random, the stories about the past that a researcher constructs from archived material are dependent on the researcher's knowledge goals, skills and research method. While archived material contains a huge amount of possible descriptions and stories, the archives are also problematic due to the risk that the large amount of material might lead the researcher astray. Ethnologist Simon Ekström made the following comment about a research situation where access to available material seemed to be endless: "the difficulty for the inquisitive mind lies not in the finding but in the selection" (Ekström 2017: 9). Both the finding of material and the subsequent selection of relevant material are also processes that depend on factors which are often beyond the researcher's control and influence. In the context I am describing, this has to do, among other things, with how the material has been listed and categorised, with a failure to follow principles that should have been given during such a process. As this article will show, a certain degree of cunning, and the ability to question the headings provided, is sometimes a necessity. Another factor is the distance that exists between the archive researcher and the archive institution, as exemplified by the procedure through which the archived material is ordered by the researcher. As a researcher, I am seldom able to see the collection I intend to work with in its entirety.

I conducted an examination of the large amount of archived material generated by the Svensk miljö project, and various details in the material influenced the direction I took in my work. But how did the selection process actually occur? Was it pure coincidence that I suddenly happened to find certain details that became bearers of meaning, or was it down to my own personal skill and experience when 
it comes to navigating a large amount of material and making the selection, the part of the process Ekström described as the most difficult? Is it possible to identify a punctum in archived material in accordance with Barthes' meaning, and can his concepts be used as tools in the methodology I am applying? Can a punctum exist in text documents as a detail in how the language is used, or in the content, or in the depiction of an unexpected subject in a series of images? Or perhaps in something of material character, like a train ticket or a dried flower or a piece of fabric inside a letter, something the creator of the archive has left behind, together with other types of envelopes, boxes, strings and other materials and devices used to seal and store the collection, which have originated from the person charged with the responsibility of arranging its contents.

The ethnologist Rebecka Lennartsson used the term "archival ethnography" to describe her work with archived documents from the 1700s, whereby she acquired knowledge piece by piece about the material-and about the people whose fates were described there in fragmented form (Lennartsson 2014: 9ff). It is a term and a notion that can also be applied to the work I have undertaken in the archives and, just like Lennartsson, I also have an ambition to describe my own method (aa: 18). In a study where the ambition is to construct a story and produce new knowledge, not just to reproduce facts, the re-use of already examined sources is necessary and represents a way to master the material step by step, and to see and utilise its potential (Gustavsson 2017).

In the Nordic Museum's archives, there are two different collections from the Svensk miliö project; Börje Hanssen's personal archive, and Gregor Paulsson's collection. The latter was stored at the Department of Art History at Uppsala University until 1979, at which time it was transferred to the Nordic Museum's archives (Grünberger 1981: 144). The material contains several hundred interviews conducted with various people in Helsingborg during the 1940s, photographs of buildings, sketches of facade designs and various compilations that the fieldworkers of the time put together after having studied literature and conducted searches in various municipal archives. I saw good possibilities to further enhance and enrich existing knowledge about the town's history of settlement based on the contents of both archive collections (Gustavsson 2019). The material appeared to have been left unused for decades, although it has been partially used by other researchers, primarily the art historian Anders Dahlgren (see Dahlgren 2016 and Dahlgren 2018). 


\section{The Malmqvist Family at Home and at Work}

Gregor Paulsson's ambition of knowledge production based on fieldwork with a focus on interviewing non-academics about their everyday life and photographing people's homes was part of a greater context. European ethnologists, art historians and architectural historians had been using fieldwork methods for decades. In order to map vanishing vernacular architecture and life style, large-scale fieldwork was organised in the rural areas of many countries during the early twentieth century (Stoklund 2003, Gustavsson 2014). During the 1930s, the method was developed by Swedish ethnologist Sigurd Erixon, among others, to also encompass urban traditions and professions (Nilsson 1996). Both Paulsson and Hanssen were strongly inspired by contemporary Anglo-Saxon sociologists such as Lewis Mumford, which can be seen in the correspondence between them, now found in the private archive of Gregor Paulsson. His choice of method to gather empirical data for the Svensk stad project was a result of inspiration from both the well-known tradition of fieldworks in rural environments in Europe and from contemporary sociological works in the United States.

Börje Hanssen was 27 years old, with a background in economic history, political science and human geography. He started his fieldwork in Helsingborg in the summer of 1942, and then returned the the city two years in a row. In 1942 and 1943, Hanssen and a couple of young researchers who were part of Paulsson's group had spent time conducting interviews and performing studies of archives and literature with the aim of mapping how industrialism had influenced both the daily lives of people and the expansion and development of the town. Hanssen had come to feel at home in the town and was well versed in both its past and present thanks to the comprehensive studies of archives and literature that he had undertaken. His activities during the summer of 1943 had included moving around the town with a camera in hand, which resulted in more than 100 photographs with descriptive captions (Gustavsson 2020). During the spring prior to the commencement of his fieldwork, he had begun to explain his views on the role of photography in the study:

As I have already said, the camera should be used to a greater extent. It often requires a certain amount of persuasion before someone will allow you to take photographs in their home, but I think that the results are well worth the effort, especially if it is possible to achieve pictures of the environment from a functional perspective, so to speak; in other words, not just fine pictures of the living room or kitchen on Sundays, but images of those rooms in everyday use during the week, with unwashed dishes and discarded bedclothes and ideally even the people who live there. Such images would definitely bring more life to the work (translation by the author). ${ }^{1}$ 
There is a large number of interviews and descriptions of various homes in Helsingborg, so a relevant question is of course: why have I chosen to focus on the example of the Malmqvist family? For one thing, compared to all the other interviews, the material regarding the Malmqvist family is unusually rich in terms of the scope of its content, and Börje Hanssen's own description suggests that the material should contain both photographs and sketches of the home. This particular example should also be able to highlight Hanssen's work methods well, in addition to a piece of rich empiricism from Helsingborg's past.

The fieldwork during the first two summers had been focused on surveys of people's homes, which was one of the primary elements of Gregor Paulsson's project. Since there was so little literature available about the changes that had taken place in Swedish homes during the last 100 years, it was necessary to ask people about it. Elderly people were asked to describe their childhood homes, and interviews were combined with visits for the purpose of observing the contemporary homes of the time. In July 1944, however, Hanssen had another assignment. On this occasion he visited a long line of shops along Kullagatan, one of the main streets in Helsingborg. His aim was to gain an overview of the range of goods on offer, the types of customers who visited the shops and their turnover, as well as the physical characteristics of the shops in terms of their furniture and fittings and the windows, displays and signs that faced the street. This was to complement the surveys of people's homes, and the purpose was similar. It had to do with collecting empirical material that would be used for descriptions and analyses of the changes that had occurred during the last 100 years. It is in this context that Hanssen visited stationer Malmqvist on Kullagatan 12. However, it soon became apparent that work and home life were closely intertwined for this self-employed businessman. Hanssen therefore also interviewed Malmqvist - and perhaps his wife as well, although that particular detail is not apparent from the material - about their home. Hanssen made notes, and he drew sketches of how the rooms were furnished, including the location of lamps. It is apparent from his documentation that he also took photographs in the couple's home.

On the first page of his account of the stationer's home, Börje Hanssen has written that it consists of 19 pages in total, plus sketches of the layout of the home and some photographs. Initially the family and their personal details are presented. The Malmqvists had two sons, one of whom attended school. The couple had married in 1935, and they were now both about 35 years old. It is stated that both the husband and the wife worked in the store, which sold books, stationery and souvenirs. Their home was a rented apartment in a detached house in the northern part of town. Hanssen goes on to describe how both the man and his wife had graduated from upper secondary school, and that both had grown 
up in what he refers to as "middle-class homes" (Volume 2 in Gregor Paulsson's collection, Nordic Museum's archives) .

The 18 pages that follow contain a description of the Malmqvists' home and everyday habits. The description covers almost the entire apartment, which consisted of three rooms and a kitchen. The living room, library, bedroom and kitchen have each been given a separate heading in Hanssen's description, but he makes no comment about the hallway, bathroom or any other areas. The family had a maid, who lived in a room in the attic of the house, but her living quarters also pass without comment in the description. Even though the questions Hanssen must have asked are not specifically listed, the account he provides makes it possible to make an educated guess. His questions related to matters such as the various pieces of furniture in the home-had they been inherited, where and when were they purchased, and how and when were they used? What was the function of the various rooms? Which mealtimes were taken at home, and which were taken at work? At the top of each page, there are a couple of keywords that summarise the contents of that particular page. The same method was employed for all the interviews from Helsingborg, with one or two keywords written at the top of each page to capture the essence of the contents of that page. The use of headings was one way of categorising the content and creating clarity, with the aim of facilitating the comparison of different interviews with each other.

Börje Hanssen's text in the description of the Malmqvists' home is based on both his own observations and what the husband and wife said, although it is very clear that Hanssen's own voice is the dominant one in the narrative. $\mathrm{He}$ often appears not only to be observing the home but also to evaluate what he sees and to record his evaluations. The Malmqvists have referred to one of the rooms as the library. In his account, Hanssen has written the word "library" in quotation marks, suggesting that he does not entirely agree with the interviewees as to whether this is, in fact, an appropriate name for the room in question. The quotation marks have clearly not just been used by accident; Hanssen has had a definite intention when using them. In the account from the home, in which the rooms, furniture, decorations and lamps are listed and described, one message in particular is highlighted.

Hanssen notes in his description how the Malmqvists draw particular attention to "the inherited pieces", and how their age and foreign origin are of importance to the couple. A clock is said to have been purchased in Paris in 1905 by the parents of one of the spouses. Hanssen also notes that the bookshelves with their books "serve the social prestige". Items of furniture, lamps and other fittings have been assigned a number that indicates their placement on a sketch of the layout of the apartment. The answers to the interview questions have been reformulated by Hanssen, although sometimes a direct quote from one of the spouses has been written in quotation marks, as extra clarification that it is, in fact, a direct quote. 
Sofa 22 must be deemed to be for display purposes and is primarily used when guests are invited. The 'library' is the closest equivalent to a drawing room in terms of its function.

When they have just a single guest, it is possible to take afternoon tea on sofa 22. 'It is low in relation to the table'.

The lamp behind it is primarily for display purposes.

When they have several guests, they eat in the living room as usual.

If they play cards, this is done in the library.

If they have offered their guests coffee only, they remain seated at the table and talk, but if a hot meal has been served and the dishes must be cleared away, they retire to the library after the meal. (translation by the author $)^{2}$

In the extract above, Hanssen refers to a sofa that is for "display purposes", and the same reference is made in relation to a lamp. In all likelihood he means that the function of the sofa is connected to when the couple is receiving guests, a situation in which the home is displayed to people other than members of the family, and is also used together with the guests. The 19 pages are mostly filled with descriptions of this nature about how the furniture is arranged and used, along with descriptions of lamps and how they are used. But there is also a considerable amount of information about the family's eating habits and everyday life. The wife takes care of the bookkeeping at home in the evening. Breakfast is taken at 08:30 in the morning and consists of porridge and milk along with some warmed-up leftovers. The husband and wife then take sandwiches to the shop, with cheese being the most common filling. During the winter, the couple both work in the shop until late in the evening, and on such occasions the maid takes care of the two boys and makes sure they get to bed on time.

Gregor Paulsson demanded that his team members kept a diary in which they were to write down all the work they had performed. The diaries were sent to Paulsson on a regular basis. In one such diary, it is recorded that Börje Hanssen conducted the interview with Malmqvist on 24 July. On that same day, he had also interviewed one other resident of Helsingborg and had visited a construction engineer who was responsible for a residential area under construction, which 
would also be included in Hanssen's study. He had also worked with maps that day. The following day he had taken photographs at the Malmqvists' home and had also carried out a number of other tasks for his assignment on behalf of Paulsson (Volume 14 in Gregor Paulsson's collection, Nordic Museum's archives). Hanssen's diary reveals that Malmqvist was just one of a great many informants. When I read the entries in the diary, I get the impression that the visit to the Malmqvist's home and shop cannot have taken too many hours to complete, even though the account of the visit is one of the most thorough and most comprehensive of all the studies undertaken in Helsingborg during the Svensk miljö project. According to Hanssen's notes, there should also be sketches of the furniture arrangements as well as photographs from the Malmqvist's home. However, these have not been stored together with the description.

\section{The Unreliable Archives}

So where were the photographs and sketches from Malmqvist's home that Hanssen's notes indicated should also have been included? They had not been placed in the same archive box as the text material, but it is not uncommon for photographs to be separated from other documents and stored on their own due to their nature and the way they must be preserved. From the archivist's perspective this is the correct manner in which to proceed, but for the user of the archives it means that material that has been created in the same context ends up in physically separate storage solutions. They were not included among the photographs on the archive list of pictures of various subject matters from Helsingborg. The fact that these sketches and photographs were missing represented an irritating gap in the material, which I felt made my interpretation of Hanssen's work more difficult and meant that I could not gain a sufficient understanding of what things really looked like in the home of the Malmqvist family in 1944.

The material gathered by Hanssen in Helsingborg was used by both Hanssen and Paulsson after the fieldwork was finished, and it had been circulating between them both and Paulsson's department in Uppsala. It was not Hanssen himself who was responsible for the making of archival records. Several of Paulsson's assistants, and later on archivists, handled the material after the project was eventually finished. So, there were many occasions for mistakes to be made.

A gap such as the one described above can have many reasons. It may be due to what the German media theorist Wolfgang Ernst calls "passive absence", in other words that something never actually existed, and other times it has been actively removed as an exercise of power (Ernst 2015: 14). In this case, however, both scenarios seemed unlikely-Hanssen himself has written that there should 
be photographs in the material, and it is difficult to find any logical reason why they would have been intentionally removed. It is therefore likely that there may have been other reasons for this particular gap in the material. It is of course possible that the photographs never existed. Perhaps Börje Hanssen simply got a bit confused about where he had been with his camera and where he had taken pictures. Alternatively, the pictures he took may not have turned out to his liking, and he may therefore never have included them in the final material. Another possibility is that they disappeared before the Svensk stad volumes were published in the early 1950s. The sketches of the furniture arrangements could have remained nothing but basic sketches that subsequently disappeared in the process when everything was to be redrawn and refined. There are many different scenarios that could explain why the images that were intended as a complement to the written material were not in the archives.

This gap, the fact that the photos and drawings of Malmqvist's home were missing, acted as a sort of punctum in my examination of the material. Barthes writes about how he perceived the lack of a connection between two different elements in a photograph, and how this made him stop and think as he observed the image (Barthes 1981:23). For me, the absence of material that should have been in the archives was a similar experience. The fact that this material was missing became a source of focus and irritation on my part, even though there were over 100 interviews from Helsingborg and it was never going to be a problem for me to achieve my knowledge goals, which were focused on the history of the town's settlement and development and the more general conditions experienced by its residents (Gustavsson 2019). There were many other interviews, photographs and sketches that I could have studied more in-depth, and the existing material from the Malmqvist family that I had in front of me was of the utmost interest as documentation for analysis and interpretation, but there was something about the material that was missing that I just could not let go of. This irritating gap in the material made it difficult for me to discard the notion that, despite everything, these photographs and sketches might actually be there somewhere, in one of the two archive collections. The punctum that this gap in the material represented encouraged me to conduct further investigations into the matter.

Archive collections are arranged and equipped with lists that aim to create order and make it easier to find a specific item among all the available material. At the same time, the manner in which a collection is classified also governs the knowledge that can be gained from it (Ernst 2015: 13ff, 88). Furthermore, despite the best intentions, archive collections always contain some degree of disorder (Myrberg 2012: 75). The order that has been created can exist on different levels, 
from having only one single heading for an entire (unlisted) collection, to a carefully listed collection with a high degree of detail. The latter case knows no finite bounds-it is always possible to make notes about a collection of documents at an even greater level of detail.

In an archive collection with only a very general, overall list of its contents, the percentage of incorrectly listed documents is lower than for a collection that has been carefully listed in detail. The higher the level of ambition regarding the degree of detail, the greater the likelihood that an error will be made. In the collections that stem from the Svensk miljo project, both of which are stored in the Nordic Museum's archives, there are lists indicating the existence of photographs from Helsingborg in several different volumes.

Volume 3 in Gregor Paulsson's collection contained a couple of pictures, the subject matter of which I found difficult to localise. I could not recognise them as being from Helsingborg (and having worked in the town for many years, I am extremely familiar with its central areas). Consequently, it seemed logical that these pictures must be from one of the other towns included in the project. Sure enough, after a few relevant comparisons, the answer quickly became apparent; these were a couple of pictures from the town of Örebro in central Sweden, which had mistakenly ended up under the heading Helsingborg. If the person who wrote the heading on this volume had been satisfied to simply write "photographs", the heading would have been correct; but the higher level of ambition to provide a greater degree of detail by also stating the name of the town gave rise to an error. Naturally we are dealing with an obvious paradox in such a situation - a lower degree of detail in the list of an archive collection creates more work for the researcher, since it is necessary to go through more volumes in order to find what you are looking for. It may be more difficult to find the object of the search, but on the other hand the likelihood of errors in the categorisation is lower.

Armed with the knowledge that a couple of Örebro pictures had incorrectly ended up in a Helsingborg volume, I was taken by the impulse to conduct a reverse search and look at some of the volumes that (according to the list) should have contained material from Örebro, even though it was never my intention to include Örebro in my study. The archive personnel fetched a volume with the notation "Åtvidaberg and Örebro". ${ }^{3}$ At the very top of its contents there was an envelope with the notation "Unnamed contact prints". The contents of that envelope included a photo reproduction of an older painting of a farm on the outskirts of Helsingborg. This was followed by photographs from Örebro, just as the volume's label had promised. 


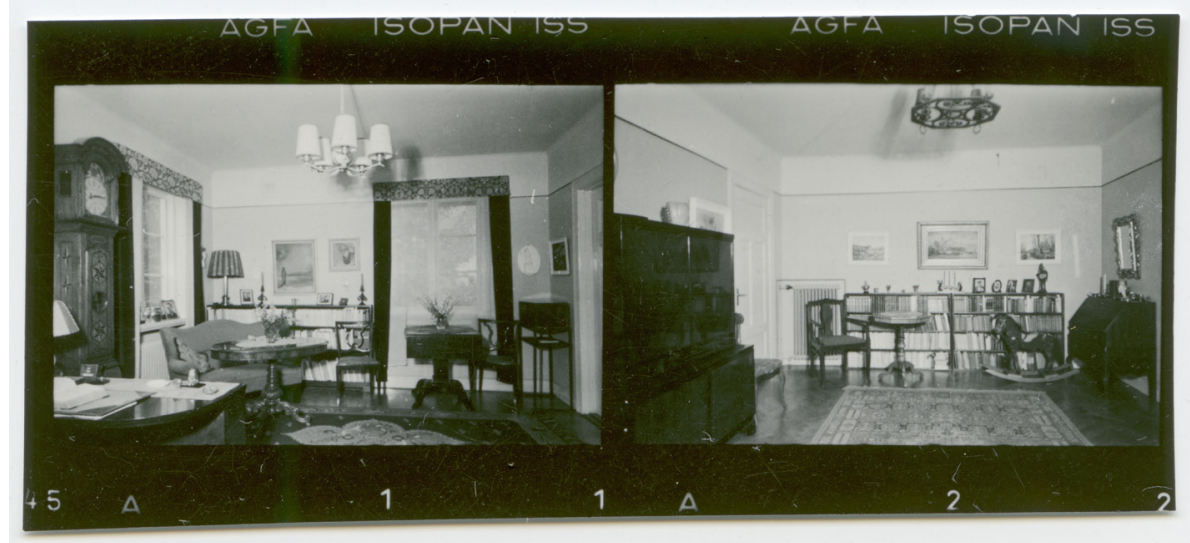

Fig. 1

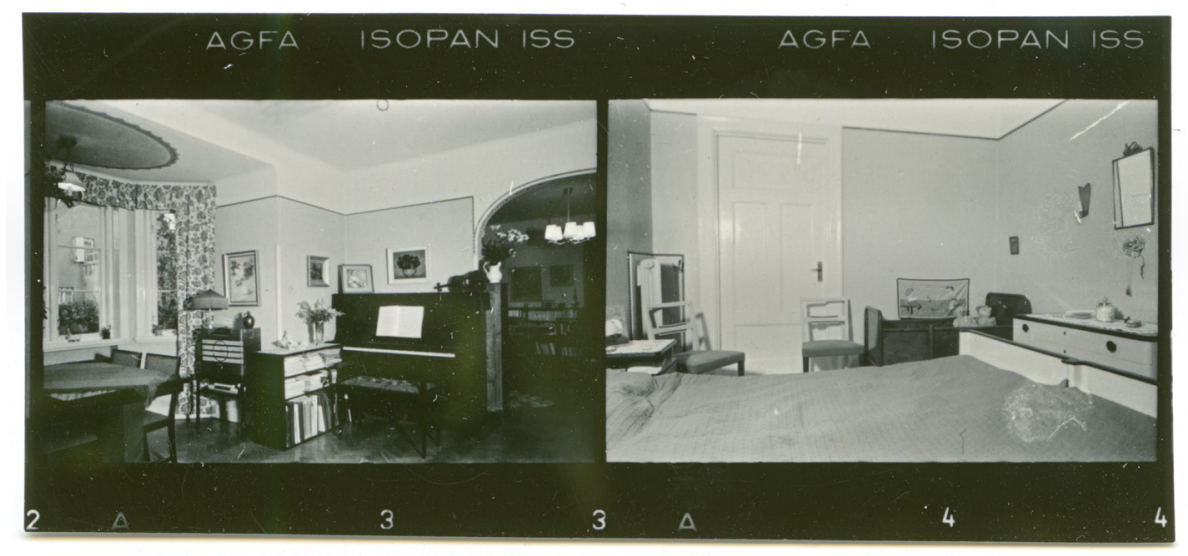

Fig 2. The photograps in Figures $1 \& 2$ originate from volume 18 in the private archive of Börje Hanssen, the Nordic museum.

The envelope also contained four contact prints in 135 film format, 24x36 mm. The images seemed to depict a home environment, and on the back of the prints the name "Malmqvist" had been written in Hanssen's handwriting, which I was now able to recognise. In other words, these were in fact the pictures that Hanssen took of Malmqvist's home, and which were missing from the volume with the Helsingborg material that contained the description of the home.

One error in the archive list had led me to the discovery of yet another error, but on this occasion the error meant that I was able to find the pictures that I had been missing. An error had in fact also been made in the notation on the outside 
of the envelope-these contact prints had indeed been named, just not with a topographic reference. All of the archive material that has been described to date in this article stems from Gregor Paulsson's collection. From the end of the project until 1979, two years after his death, it was stored at his department in Uppsala, where it is likely that the order that had been created in the various archive boxes remained the same as it had been during the time of the project. The art historian Anders Dahlgren has described the "chaotic circumstances" that, to some extent, characterised the Svensk miljö project (Dahlgren 2016: 78). The disorder that exists in the collections, with misleading headings and clearly incorrectly placed objects, can be seen as a reflection of the conditions (disorder) that prevailed during the project itself (compare with Gustafsson Reinius 2009: 86ff).

So, did I really need these photographs for my work? Did they enable me to draw conclusions that I would not otherwise have been able to? Barthes refers to the photograph's relationship to its subject matter as indissoluble; "A specific photograph, in effect, is never distinguished from its referent" (Barthes 1981: 5). And I must concur that this was indeed the case. Despite the thorough written descriptions of Malmqvist's home, it was not until I was also able to place these small photographs in front of me that I could really understand what Hanssen had seen. Now I was seeing exactly what Hanssen had seen through his lens; that which he had chosen to photograph, or perhaps that which he was able to or had been given permission to photograph. The photograph points something out to the observer (Barthes 1981: 5).

The Malmqvist family are not in view in the pictures, but their candelabras, curtains and rugs are, and this makes it possible to recognise the furniture arrangements described in Hanssen's texts. The floors are polished, and everything looks well cleaned and in orderly condition. Trees can be glimpsed through the thin curtains in the windows. My sensation when viewing the pictures is that this was probably a comfortable home; and such a sensation could not have been experienced simply by reading Hanssen's descriptions.

There is also one photograph of the bedroom. This is an indication that the family were prepared to let Hanssen into their more private, intimate sphere. $\mathrm{He}$ has not simply stood in the doorway looking into the room; he has entered and has taken a picture facing the doorway and the area beyond. It looks to have been a very confined space. There is a double bed in the middle of the room. A child's bed is positioned against a wall. In Hanssen's account, he reports a statement by one of the parents that they would eventually have to move to another home, so that their sons could have a room of their own. The photograph only shows one child's bed, but the text confirms that the entire family slept in one and the same room. The text and the photography provide confirmation of each other, and the fact that Hanssen was permitted to enter the bedroom in such a manner tells me 
something about the situation that existed when he visited the Malmqvists' home. In this respect there are many different possible scenarios that can be considered. Was it an indication that the young stranger with his camera had succeeded in winning the trust and confidence of the Malmqvist family, or should the situation be interpreted as some form of submissiveness on the part of the family when visited by an academic researcher working on an important assignment? The photographs from the Malmqvist's home invite their observer to indulge in speculation regarding the situation in which they originated, but the only thing we can truly know for sure is that at least four pictures were taken.

The answer to my initial question regarding the necessity of the photographs is twofold. On the one hand, they gave me a lot. They brought me closer to both Hanssen and the Malmqvist family than I could ever have come if I had only been able to read Hanssen's descriptions. In exploring people's everyday life, images like these are outstanding sources (Burke 2001:81). The presence of these photographs also aroused questions regarding the rooms and living areas that were not visible in them-the kitchen, the hall, the broom cupboard, the bathroom-what did those areas look like, and why did Hanssen take no pictures of them? On the other hand, it would of course have been possible for me to use the written material available as empiricism even without the photographs, but in that case the results of my analyses and interpretations would have been different.

The fact that the sketches of the furniture arrangements were still missing was of no great consequence to me (but perhaps they would have been of more importance to another researcher). I would certainly have been interested in seeing a sketch of the layout of the entire apartment, in order to better understand the position of the rooms in relation to each other, but it is reasonable to assume that Hanssen's sketches contained only the same information that is already available in his written description of the home.

\section{The Peripheral Details}

During my work in the archives I also came across other pictures that seemed to be peripheral to the context in which I was primarily interested, namely the history of the town's settlement and development. Earlier in this article I mentioned a series of pictures that Hanssen took during the summer of 1943, the subject matter of which consists of buildings, streets and places in Helsingborg (Gustavsson 2020). There is one exception however: a picture that depicts the interior of a room with a bed against a wall. 


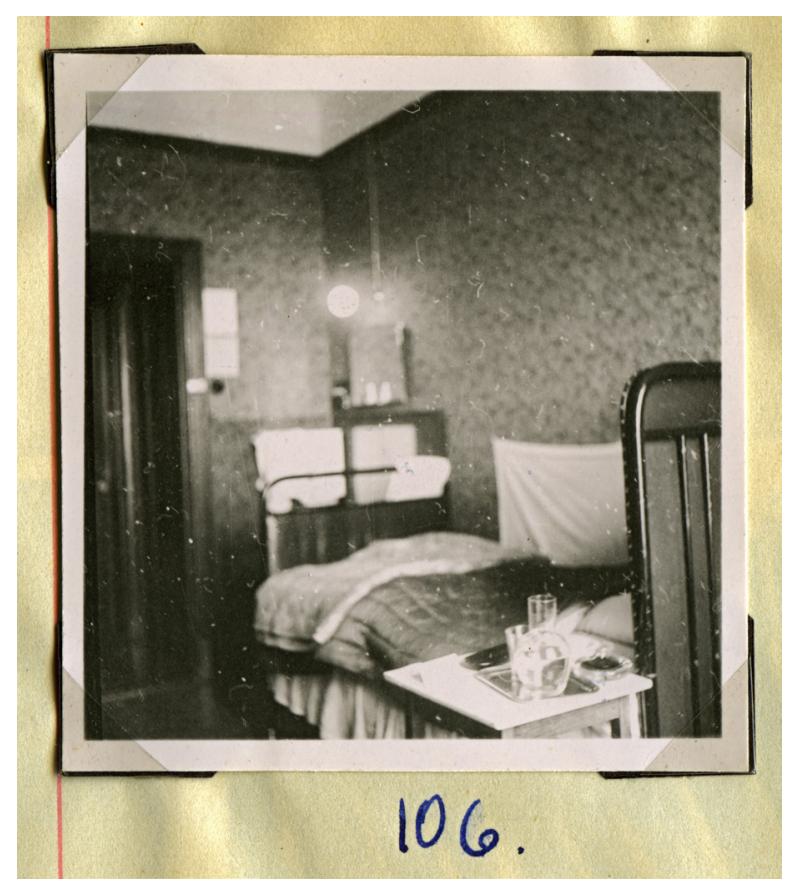

Fig 3. The picture in figure 3 originates from volume 69 in Gregor Paulsson's collection, the Nordic museum.

The bed is made up, but there is no bedspread. A glass of water rests on a table next to the head of the bed, and there appears to be a mirror on the wall, with a glowing, spherically shaped wall lamp above it. The image is fuzzy, and it is not possible to discern all the details it contains. It has been denoted as number 106 in the number series Hanssen applied to his pictures. According to his notes, this picture was taken in a room at the Hässleholm City Hotel on August 5 at 7 in the morning. The town of Hässleholm is a railway hub located about 80 kilometres to the east of Helsingborg, and when this picture was taken, Börje Hanssen had already finished his 1943 fieldwork in Helsingborg and was on his way to another location to continue his endeavours.

Börje Hanssen himself is not visible in a single photograph from the fieldwork conducted in Helsingborg, but this image of the room he stayed in during his journey from Helsingborg provided me with a closer connection with his work. This one photograph, seemingly lacking any connection to the other photographs and the interviews from Helsingborg, gave me a better sense of the conditions of the fieldwork Hanssen performed, something that has not been conveyed in any of his texts. The large amount of documents included in the archive collections that are a result of his work gave me an understanding of his intellectual capacity 
through the questions he had formulated, the great many interviews he had conducted, and the traces of the archive and literary studies he had undertaken. The image of the bed in the hotel room early in the morning made me think of a tired person, on a journey a long way from home to undertake fieldwork that, based on the material I have studied, seems to me to have been extremely demanding, intellectually, socially and physically speaking. My focus was on the fieldwork in Helsingborg during the 1940s. The image of the hotel room had absolutely nothing to do with that. Yet, at the same time, it came to represent a link between then and now, between me-a researcher in the twenty first century studying the conditions for research undertaken in the 1940s-and the individuals who were active in the performance of the research at that time. In my examination of a large amount of material, this one individual photograph came to be a punctum in the archive collection, something that turned my thoughts in a new direction. The photograph constituted a "surprising oddity" that facilitated new thoughts in new directions (Gustafsson Reinius 2009:81).

In relation to the context I was studying-Hanssen's fieldwork in Helsingborg -this was initially a photograph without any empirical content and yet, it came to be filled with meaning. Even though no person is visible in the picture, it was still able to convey the experience of the conditions of the fieldwork at that time. The fact that Hanssen not only dated it but also noted the time of day at which it had been taken also made it possible to place it into a context, and this information, together with the image itself, was like a diary entry from the fieldwork. The photographs from Helsingborg in the summer of 1943 are dated from the middle of July until August 3. The following day, Hanssen commenced his journey from the town and, after spending one night in Hässleholm, he continued on his way to some new destination on August 5. The other photographs, that were initially missing and that I subsequently found, had the character of a sort of trophy, as archive finds sometimes do. In terms of knowledge they contributed to the progress and quality of my work. But this seemingly meaningless photograph, together with the notes about where and when it was taken, was filled with meaning in another way.

\section{What is Needed, and when is it Finished?}

Initially I considered the question of the skills that are needed when navigating a large amount of material. Simon Ekström comments that it is not the actual finding of the material but rather the selection process that represents the true difficulty (Ekström 2017: 9). But when the archive's classifications are inadequate or incorrect, which caused me problems when I was looking for the entire material from the home of stationer Malmqvist, the actual finding of the material is also characterised by difficulty. Practical factors like the available time and 
resources govern the work of searching in archives, but so does the competence that enables the researcher to determine when it is time to stop looking and start the final selection process. Such competence is developed as experience is added to experience, for example when it becomes possible to identify a particular individual's handwriting. Local knowledge about the place from which the material stems also contributes to understanding. In this context it is also necessary to include the ability to create meaning out of something that may initially appear to be meaningless, whereby punctum as an analytical concept is a useful tool.

I have examined a part of Hanssen's work in Helsingborg in the mid-1940s, where both his fieldwork and the result of it-the archival records-have been of importance. Not only the documents themselves but also the archival structure, in other words how the material was organised, are considered as important sources of knowledge. In the selection process, a search for meaning-bearing details has been crucial. The details that stick out may initially appear to be only peripheral in nature, but such details can highlight the conditions that the rest of the material - studium in Barthes' meaning-fails to capture. The presence of punctum is not always detected the moment the researcher reads a text, searches documents in the archive or examines a picture. It is in the nature of punctum that it comes into sight when a research process has been ongoing for a while, after hours, days and perhaps weeks examining sources with the character of studium, when a feeling of information overflow might appear. The absence of something expected can also operate as punctum when such an absence makes it necessary to change focus and detect meaning from what available and unavailable sources can nonetheless say.

As we have seen from the examples discussed in this article, a shortcoming in the cataloguing of material is in itself a bearer of knowledge about how the collection has been managed. Initially, the collection was not placed in order and listed by professional archivists but is instead still arranged and stored on the basis of the logic that prevailed when it was first created during the 1940s and 1950s. Consequently, the collection represents knowledge about the work processes of a time gone by, in a manner that would not have been possible if it had been the subject of thorough professional measures to put it in order and list it accurately based on the new order (c.f. Engström 2015: 254, where an "archive-archaeological" method is described). The lack of consistency in the archive collection that I gradually discovered during my work with the material provided me with experience that eventually led me to find the "right" box. The ability to question the order denoted by the labels on the archive boxes hinted at the necessity to search still further, and it is such an ability to question categorisations, based on experience gained from misleading or incorrect headings, which appears as both a method and a competence in relation to archive research work. 
Karin Gustavsson holds a $\mathrm{PhD}$ in ethnology. She teaches ethnology and museology at the department for arts and cultural sciences at Lund university, and is also the manager of the Folk Life Archive at Lund university. Her research interest is mainly in the field of cultural history. The current article has derived from a research project that explores the archive of the Swedish town project from the 1940s and 1950s. Email: karin.gustavsson@folklivsarkivet.lu.se

\section{Notes}

1 The text in original: Som jag redan tidigare sagt, borde kameran komma till användning i mycket högre utsträckning. Det fordras ofta en viss övertalning för att få fotografera i hemmen, men jag anser att resultaten skulle vara väl värda besväret, speciellt om man sökte få fram miljöbildernas så att säga funktionsutseende: inte paradrummet eller köket på söndagarna utan i vardagslag, med disk och sängkläder och gärna även människor. Sådana bilder skulle ge åtskilligt mera liv åt arbetet. Hanssen to Paulsson 06/04/1943, vol. 501 G:1 in Gregor Paulsson's personal archive, UUB

2 Soffan 22 måste anses vara representativ och användes huvudsakligen då man har gäster. 'Biblioteket' motsvarar närmast finrummet till funktionen.

Då det är någon gäst kan man inta te i soffan 22. 'Den är ju låg i förhållande till bordet'

Lampan bakom väsentligen representativ.

Då det är gäster, äter man som vanligt i vardagsrummet.

Spelar man kort, sker det i biblioteket.

Har man bjudit på kaffe enbart, sitter man kvar vid mellanbordet och pratar, men har man bjudit på varmrätt och skall dukas av, drar man sig ut i biblioteket efteråt.

Volume 2 in Gregor Paulsson's collection, Nordic Museum's archives.

3 Volume 18 in Gregor Paulsson's collection, Nordic Museum's archives. Åtvidaberg is a small town in the southeast of Sweden.

\section{References}

\section{Archives}

Nordiska museets arkiv, / Nordic museum

Börje Hanssens personarkiv / Private archive of Börje Hanssen

Gregor Paulssons samling / Gregor Paulsson's collection

Uppsala universitetsbibliotek / University Library of Uppsala

Gregor Paulssons personarkiv / Private archive of Gregor Paulsson 


\section{Culture Unbound}

Journal of Current Cultural Research

\section{Literature}

Barthes, Roland (1981): Camera Lucida: Reflecions on Photography. New York: Hill and Wang.

Burke, Peter (2001): Eyewitnessing: The Use of Images as Historical Evidence. Lo ndon: Reaktion Books.

Ekström, Simon (2017): Humrarna och evigheten. Kulturhistoriska essäer om konsumtion, begär och död. Göteborg: Makadam.

Dahlgren, Anders (2016): "The Svensk stad (Swedish Town) Project-Architectural History in Action. Konsthistorisk tidskrift/Journal of Art History, 85:1, 76-84.

https://www.tandfonline.com/doi/full/10.1080/00233609.2015.1116023

Dahlgren, Anders (2018): "Fullständigt otillförlitlig, men absolut oumbärlig". En historiografisk undersökning av projektet Svensk stad, doctoral dissertation. Göteborg University.

https://gupea.ub.gu.se/handle/2077/54585

Engstöm, Elin (2015): Eketorps veckningar. Hur arkeologi formar tid, rum och kön, doctoral dissertation. Stockholm University.

Ernst, Wolfgang (2015): Stirrings in the archives: order from disorder. Lanham, MD: Rowman \& Littlefield.

Grünberger, Tulla (1981): “Arkivmaterialet till Svensk stad”. Thomas Hall \& Ingrid Hammarström (eds.) Perspektiv på Svensk stad. Staden som forskningsobjekt 1950 1980. En skrift från projektet Svensk stadsmiljö, byggande och boende under de senaste hundra åren. Stockholm: Akademilitt., 144-155.

Gustafsson Reinius, Lotten (2009): "Sensing through white gloves: On Congolese objects in Swedish Collections". In: The Senses \& Society, Vol. 04, no 01. 75-97.

http://eds.b.ebscohost.com/eds/detail/detail?vid=0\&sid=522cd676-854e-4600-9d35 $-5 \mathrm{c} 0$ cef4ce $2 \mathrm{ca} \% 40$ sessionmgr 120\&bdata $=$ JnNpdGU9ZWRzLWxpdmUmc2NvcGU9c210ZQ $\% 3 \mathrm{~d} \% 3 \mathrm{~d} \# \mathrm{AN}=38698569 \& \mathrm{db}=\mathrm{a} 9 \mathrm{~h}$

Gustavsson, Karin (2014): Returning to the Archive in Search of Everyday Practices in Fieldwork. Ethnologia Europaea, Journal of European Ethnology. Vol 44:2. 61-75.

Gustavsson, Karin (2017): Kunskap ur tomrum. Närläsning som etnologisk metod. Lars-Eric Jönsson, \& Fredrik Nilsson (eds.) Kulturhistoria. En etnologisk metodbok. Lund: Institutionen för kulturvetenskaper, Lunds universitet.

https://lup.lub.lu.se/search/publication/97af2335-280c-47c5-b7ab-eb1dcb4e6d54

Gustavsson, Karin (2019): "Platsen för industrialismens drama. Om Söder i Helsingborg och bokverket Svensk stad". Pål Brunnström \& Ragnhild Claesson (ed). Creating the city: Identity, Memory and Participation. Conference proceeding. Malmö, Malmö University, 161-179.

Gustavsson, Karin (2020): "What Börje Hanssen saw: About photographic imagery and knowledge of a town". Peter Aronsson, Andrej Slávik \& Birgitta Svensson (eds). Images in History / History in Images. Towards an (audio)visual historiography. Kungl. Vitterhets Historie och Antikvitets Akademien Series: Konferenser 99, 59-72.

Götselius, Tomas (2008): “Åter till arkivet”. Foreword. Wolfgang Ernst. Sorlet från arkivet. Ordning ur oordning. Göteborg: Glänta.

Lennartsson, Rebecka (2014): "Arkivetnografi eller reflektioner över en tappad biljett”. Kulturella Perspektiv 2014:3, 8-19.

Löfgren, Orvar (1996): "Ett ämne söker sin väg”. Billy Ehn \& Orvar Löfgren (eds.) Vardagslivets etnologi. Reflektioner kring en kulturvetenskap. Stockholm: Natur och kultur, 13-87.

Löfgren, Orvar (1997). "Scenes from a troubled marriage: Swedish ethnology and material culture studies". Journal of material culture. 1997(2):1, 95-113. 
Myrberg Burström, Nanouschka (2012): "A Study of Punctuality: Using typo-chronology as Barthes' studium and punctum". Nanouschka Myrberg Burström \& Fredrik Fahlander (eds.) Matters of Scale: Processes and courses of events in the past and the present. Stockholms universitets förlag, 75-89.

Nilsson, Bo G. (1996): Folkhemmets arbetarminnen. En undersökning av de historiska och diskursiva villkoren för svenska arbetares levnadsskildringar, doctoral dissertation, Stockholm University.

Stoklund, Bjarne (1980): “Börje Hanssen 1917-1979”. Ethnologia Scandinavica. A Journal for Nordic Ethnology 1980, 155-157.

Stoklund, Bjarne (2003): "Ethnology and vernacular architecture. Revisiting a classical field of study". Ethnologia Scandinavica vol 33, 5-20.

Svensson, Birgitta (2012). Varför etnologi?:En ämnesintroduktion för nya studenter. 1. uppl. Lund: Studentlitteratur. 